\title{
Macroaggregates of Emiliana huxleyi in sediment traps
}

\author{
G. C. Cadée \\ Netherlands Institute for Sea Research, P.O. Box 59, Texel, Netherlands
}

\begin{abstract}
Sediment traps used during REFLEX (REpeated FLadenground EXperiment, North Sea) collected macroaggregates of the coccolithophorid Emiliana huxleyi just after their maximum of abundance in surface water. Such macroaggregates have not been described earlier for this worldwide phytoplankter, they are fragile and therefore probably destroyed during normal sampling procedures. Comparable aggregates are described for 2 other coccolithophorids (Bernard 1939, 1953, 1963), they are probably important in the transport of coccoliths to the seabottom and may be more widespread among coccolithophorids.
\end{abstract}

Sediment traps are valuable tools for studying the flux of particles from surface to seabottom (Honjo 1980, Blomquist \& Håkanson 1981, Angel 1984). During REFLEX, funnel-shaped, floating 'Kiel-type' (Zeitzschel et al. 1978) sediment traps were used (without multisample apparatus), to obtain information on the downward flux of organic carbon from the euphotic zone in the Fladenground, North Sea. Traps were attached to a drifting buoy launched at $58^{\circ} 42.5^{\prime} \mathrm{N}$, $0^{\circ} 28.5^{\prime} \mathrm{E}$, which followed the water layer at 10 to $20 \mathrm{~m}$ depth from April 27 to May 25 (1983) and moved 40 miles north during this period (Tijssen 1985). Every 24 or $48 \mathrm{~h}$, depending on weather conditions, the traps were recovered and replaced. Traps were situated at 40,65 and $70 \mathrm{~m}$ depth, i.e. below the euphotic zone but well above the seabottom (120 to $160 \mathrm{~m}$ ) to minimize trapping of resuspended bottom material. In the same area resuspended bottom material was collected in traps to some $100 \mathrm{~m}$ above the seabottom before the formation of a thermocline, and to $40 \mathrm{~m}$ above the seabottom afterwards (Davies \& Payne 1984).

Samples for phytoplankton counts were collected in the surface layer (15 $\mathrm{m}$ depth); after 19 May samples from $0,3,9$, and $15 \mathrm{~m}$ were combined because the then abundant flagellate Corymbellus aureus tended to be unevenly distributed through the surface layer (see also Gieskes \& Kraay 1984). A succession of phytoplankton was observed (Fig. 1) comparable to that described for spring 1976 in the same area (Wandschneider 1980). Chaetoceros spp., including large chain-formers, were present at the start of the study indicating the end of the spring diatom bloom. They were followed by peaks in abundance of Emiliana huxleyi and of a small centric diatom Thalassiosira conferta. Following a $4 \mathrm{~d}$ break in observations, a colonial flagellate (C. aureus) and other unidentified microflagellates were dominant.

Part of the material collected in the traps was studied microscopically before homogenizing the material for further subsampling. It consisted mainly of faecal pellets and phytodetritus (either broken faecel pellets or marine snow; Silver et al. 1978), comparable to earlier results in this area (Davies \& Payne 1984). The faecal pellets were not produced by copepods, the most important zooplankton organisms present (Krause \& Trams 1982, 1983, Fransz \& Diel 1985), in fact their easily recognizable pellets (Martens 1978) were observed only sporadically in the traps. Copepod pellets were apparently recycled in the euphotic layer as observed earlier (Paffenhöfer \& Strickland 1970 Krause 1981). Most pellets were large (up to several mm long), rod-shaped and belonged to euphausids, but other unidentified types were also collected.

Traps on 8 to 9 May contained large aggregates (Fig. 2) consisting almost exclusively of intact Emiliana huxleyi cells, embedded in mucoid material. These occurred following the peak of abundance of this coccolithophorid in surface waters $\left(1.45 \times 10^{6}\right.$ cells $\mathrm{dm}^{-3}$ ). The ovoid form of the aggregates resembled faecal pellets (not those of copepods which have a higher length/width ratio of $\sim 7$; Martens 1978). However, all cells appeared undamaged, suggesting they had not been passed through a digestive tract (intact coccolithophores have been observed in copepod faecal pellets together with loose coccoliths; Honjo \& Roman 1978). Moreover, one would expect other phytoplankton remains in addition to E. huxleyi in a faecal 

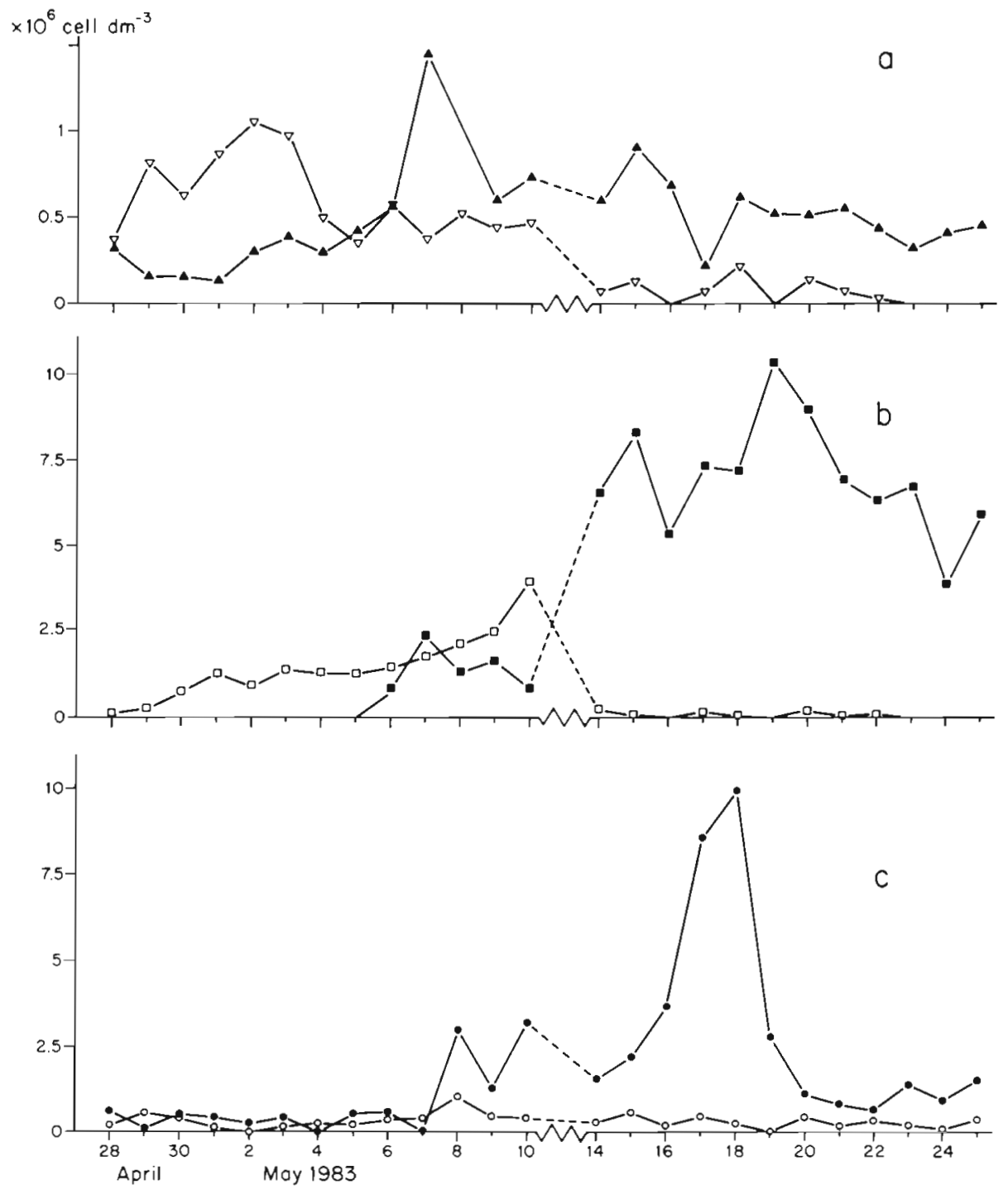

Fig. 1. Phytoplankton composition of surface water, Fladenground (North Sea) from April 28 to May 25 (1983). (a) A Emiliana huxleyi, $\nabla$ Thalassiosira conferta; (b) $\square$ Chaetoceros spp., - Corymbellus aureus; (c) $O$ all other diatoms, $\bullet$ all other flagellates

pellet of a herbivore since other phytoplankton species of comparable size were available (Fig. 1).

Aggregates of coccolithophorids have been described for 2 other species: macroaggregates of $\mathrm{CyC}_{\mathrm{C}}$ lococcolithus fragilus ('palmelloid stages') observed from the Mediterranean (Bernard 1939, 1953, 1963); and aggregates of Umbellicosphaera sibogae collected in traps in the Panama basin at 890,2,590 and 3,560 m after a bloom of this species in the surface layer (Honjo 1982). Diatoms may also form macroaggregates of comparable size and form after blooming, and subsequent sinking to the seabottom has recently been observed (Smetacek 1985). Smetacek suggests this to be a crucial part of their survival strategy: the population is rapidly removed from an inhospitable environment and a refuge population is established at depth or on the bottom. Macroaggregates of coccolithophorids may serve a similar function. They also may be more com- mon than hitherto observed. Macroaggregates are fragile and may not be adequately sampled by conventional sampling methods (Bernard 1939, Silver et al. 1978, Eisma et al. 1983). Some suggestions for aggregate formation in other coccolithophorid spp. can be traced in the literature: 'Kettenbildung' (chain-formation; Lohmann 1920) was observed in 3 species (Calyptrosphaera oblonga, Calcidiscus leptopora, Cyclococcolithus fragilis); for the latter species macroaggregates were later observed (Bernard 1939, 1953, 1963); 'Kettenbildung' and mucus formation was found occasionally in many species by Schiller (1925); a cluster of Gephyrocapsa oceanica cells was observed in Australian waters (Hallegraeff 1984); Cruciplacolithus neohelis formed aggregates in laboratory cultures (Honjo 1977)

Sedimentation of coccoliths on the seabottom can probably only take place when they are transported in 


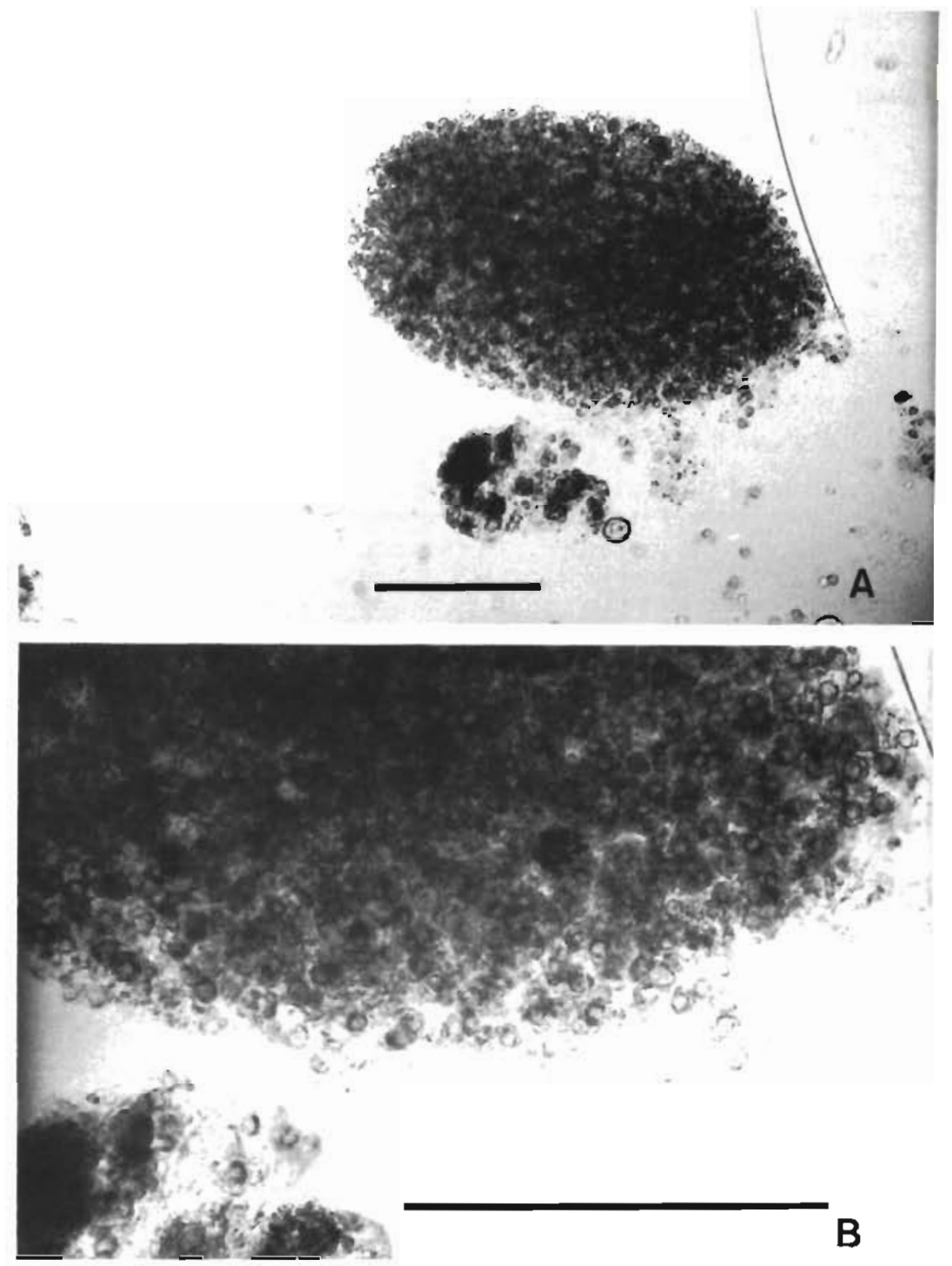

Fig. 2. Emiliana huxleyi. (A) Macroaggregate from sediment trap $65 \mathrm{~m}$ depth, Fladenground (North Sea) containing about 15,000 intact cells; bar: $100 \mu \mathrm{m}$. (B) Enlarged part of same macroaggregate; bar: $100 \mu \mathrm{m}$. (C) SEM photograph of intact cells from homogenized material from the same sediment trap; bar: $10 \mu \mathrm{m}$.

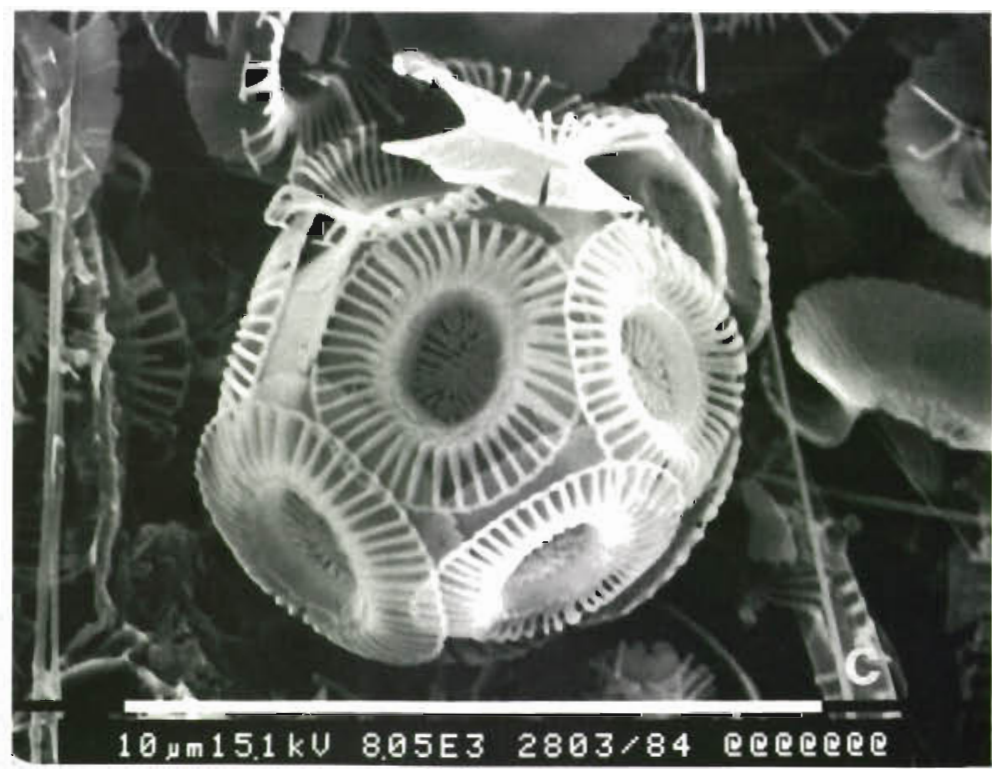


macroaggregates or faecal pellets (Honjo \& Roman 1978). Loose coccoliths (sinking rate $\sim 10 \mathrm{~cm} \mathrm{~d}^{-1}$, Honjo 1976) will probably never reach the seabottom, intact cells (sinking rate $\sim 1 \mathrm{~m} \mathrm{~d}^{-1}$, Smayda 1971) also need a much longer time than macroaggregates (sinking rate $\sim 100 \mathrm{~m} \mathrm{~d}^{-1}$, Smayda 1971 ) to reach the seabottom.

\section{LITERATURE CITED}

Angel, M. V. (1984). Detrital organic fluxes through pelagic ecosystens. In: Fasham, M. J. R. (ed.) Flows of energy and materials in marine ecosystems. Plenum, New York, p. $475-516$

Bemard, F. (1939). Recherches sur les Coccolithophorides I. Principales espèces du plancton à Monaco. Bull. Inst. océanogr. Monaco 767: 1-19

Bernard, F. (1953). Rôle des flagellés calcaires dans la fertilité et la sédimentation en mer profonde. Deep Sea Res. 1: $34-46$

Bernard, F. (1963). Vitesse de chute en mer des amas palmelloides de Cyclococcolithus. Ses conséquences pour le cycle vital des mers chaudes. Pelagos 1: 5-34

Blomquist, S., Håkanson, L. (1981). A review on sediment traps in aquatic environments. Arch. Hydrobiol. 91: 101-132

Davies, J. M., Payne, R. (1984). Supply of organic matter to the sediment in the northern North Sea during a spring phytoplankton bloom. Mar. Biol. 78: 315-324

Eisma, D., Boon, J., Groenewegen, R., Ittekkot, V., Kalf, J., Mook, W. G. (1983). Observations on macro-aggregates, particle size and organic composition of suspended matter in the Ems estuary. In: Degens, E. T., Kempe, S., Soliman, H. (ed.) Transport of carbon and minerals in major world rivers. Mitt. Geol.-Paläont. Inst. Univ. Hamburg Sonderbd. 55: $295-314$

Fransz, H. G., Diel, S. (1985). Secondary production by Calanus finmarchicus (Copepoda: Calanoidea) in a transitional system of the Fladen Ground area (Northern North Sea) during spring 1983. J. mar. biol. Ass. U.K. (in press)

Gieskes, W. W., Kraay, G. W. (1984). Analysis of phytoplankton pigments by HPLC before, during and after mass occurrence of the microflagellate Corymbellus aureus Green during the spring bloom in the Fladen Ground area of the North Sea in 1983. Coun. Meet. int. Coun. Explor. Sea C.M.-ICES/B: 15

Hallegraeff, G. M. (1984). Coccolithophorids (calcareous nanoplankton) from Australian waters. Botanica mar. 17: $229-247$
Honjo, S. (1976). Coccoliths: production, transportation and sedimentation. Mar. Micropaleont. 1: 65-79

Honjo, S. (1977). Biogenic carbonate particles in the ocean $i$ do they dissolve in the water column? In: Andersen, N. R. Malahoff, A. (ed.) The fate of fossil fuel $\mathrm{CO}_{2}$ in the oceans. Plenum, New York, p. 269-294

Honjo, S. (1980). Material fluxes and modes of sedimentation in the mesopelagic and bathypelagic zones. J. mar. Res. 38: $53-97$

Honjo, S. (1982). Seasonality and interaction of biogenic and lithogenic particulate flux at the Panama Basin. Science 218: 883-884

Honjo S., Roman, M. R. (1978). Marine copepod fecal pellets: production, preservation and sedimentation. J. mar. Res. 36: $45-57$

Krause, M. (1981). Vertical distribution of faecal pellets during FLEX '76. Helgoländer Meeresunters. 34: 313-327

Krause, M., Trams, J. (1982). Vertical distribution of copepods (all developmental stages) and other zooplankton during spring bloom in the Fladen Ground area of the North Sea. Neth. J. Sea Res. 16: 217-230

Krause, M., Trams, J. (1983). Zooplankton dynamics during FLEX '76. In: Sündermann, J., Lenz, W. (ed.) North Sea dynamics. Springer, Berlin, p. 632-661

Lohmann, H. (1920). Die Bevölkerung des Ozeans mit Plankton. Arch. Biontologie 4: 1-617

Martens, P. (1978). Faecal pellets. Fiches Ident. Zooplancton 162: $1-4$

Paffenhofer, G. A., Strickland, J. D. H. (1970). A note on the feeding of Calanus helgolandicus on detritus. Mar. Biol. 5: 97-99

Schiller, J. (1925). Die planktonischen Vegetationen des adriatischen Meeres. Arch. Protistenk. 51: 1-128

Silver, M. W., Shanks, A. L., Trent, J. D. (1978). Marine snow: microplankton habitat and source of small-scale patchiness in pelagic populations. Science 201: 371-373

Smayda, T. J. (1971). Normal and accelerated sinking of phytoplankton in the sea. Mar. Geol. 11: 105-122

Smetacek, V S. (1985). Role of sinking in diatom life history cycles: ecological, evolutionary, and geological significance. Mar. Biol. 84: 239-251

Tijssen, S. B. (1985). Hydrography at a drift station in the FLEX area. Ann. Biol. 40: in press

Wandschneider, K. (1980). Die Artensukzession des Phytoplanktons während der Frühjahrsblüte 1976 im Fladengebiet (nördliche Nordsee). Mitt. Inst. allg. Bot., Hamburg 17: 39 -48

Zeitzschel, B., Diekmann, P., Uhlmann, L. (1978). A new multisample sediment trap. Mar. Biol. 45: 285-288

Accepted for printing on April 5, 1985 